\title{
DAMPINGAN PEMAHAMAN FIQIH WANITA: PENGETAHUAN TENTANG DARAH HAID DI DESA SEMAMBUNG
}

\author{
Faisal Faliyandra, Lailatul Hasanah, Nur Safiatun, Lailatul \\ Akmaliyah, \& Kamaliatul Ilmiyah \\ STAI Nurul Huda Kapongan Situbondo, Indonesia \\ faisalfaliyandra@gmail.com, chailasing97@gmail.com, \\ sofiatun281099@gmail.com, alyafaqat434@gmail.com, \\ kamilatulilmiah75@gmail.com
}

\begin{abstract}
The problem of women's fiqh, specifically the practice and concept of menstrual blood, is the main problem in Semambung Village, so it is very important to overcome these problems. So the focus of the assistance that will be carried out is to provide an understanding of the concept and practice of menstrual blood which is part of women's fiqh. The method used in community service uses PAR (Participatory Action Research). There are several results from this assistance that have changed the social conditions of the community, such as; 1) growing awareness of women about menstruation; 2) there is a change in attitudes from various community and religious leaders in the form of social support for program implementation. Hopefully in the future, there will be research on the important role of community and religious leaders on programs related to religious understanding.
\end{abstract}

Keyword: Women's Fiqh, Menses, Community Based 
Research

\section{Pendahuluan}

Desa Semambung merupakan desa yang tergolong paling kecil di Kecamatan Jati Banteng Kabupaten Situbondo yang memiliki ketinggian -/+ 5-/100 m dari permukaan tanah. Jika diliat dari kondisi sosial ekonomi desa ini masih menggantungkan dirinya pada sektor pertanian karena termasuk daerah kawasan agraris. Kegiatan ekonomi yang berkembang di desa Semambung dipengaruhi oleh kegiatan sosial keagamaan yang sebagian besar diikuti oleh unsur pemuda, tokoh agama, kaum perempuan dan lain-lain dan dapat dijadikan wahana transfer pemberdayaan masyarakat yang berkelanjutan dan berkeseimbangan, sehingga diharapkan dapat menjadi embrio bagi kelanjutan pembangunan desa Semambung. Juga ketika dilihat dari sosial budaya, masyarakat desa Semambung sangat kental dengan budaya Islam. Hal ini dapat dimengerti karena hampir semua desa di Kabupaten Situbondo sangat kuat terpengaruh pusat kebudayaan Islam yang tercermin dari keberadaan Pondok Pesantren yang ada di Situbondo.

Namun ketika melakukan pengamatan lapangan atau observasi awal, banyak permasalahan yang dapat dilihat dari segi sosial budaya. 
Masyarakat di desa Semambung ini sangat minim sekali tentang tentang ilmu keagamaan sehingga praktiknya keluar dari sunnatullah. Ada dua permasalahan yang dapat dilihat dari budaya keagamaan, yaitu sholat jenzah dan darah haid. Untuk shalat jenazah sudah ada pembimbing dari tokoh agama yang memperbaiki praktik masyarakat desa Semambung, namun permsalahan utama yang masih dicari jalan keluarnya yaitu tentang darah haid. Beberapa permasalahan tentang darah hadi yang terjadi di desa Semambung antara lain; 1) ketika sudah haid masyarakat jarang mengganti pakaiannya; 2) masih berpuasa ketika masih haid; 3) kurang paham batas waktu tentang haid; 4) cara menghitung haid belum memahami; 5) masyarakat masih belum paham tentang istihadhah. Ini menjelaskan betapa pentingnya memberikan pemahaman kepada masyarakat desa Semambung, khususnya kaum wanita tentang fiqih wanita.

Berdasarkan beberapa pemaparan tentang permasalahan diatas, dapat ditarik sebuah benang merah bahwa sangat penting sekali pemahaman mendasar fiqih wanita kepada kaum wanita masyarakat di Desa Semambung. Lebih mengkrucut lagi permasalahan ini dapat memperbaiki konsep dan praktik tentang darah haid di Desa Semambung. 


\section{Metode}

Pengabdian masyarakat yang dilaukan di desa Semambung menggunakan PAR (Participatory Action Research). Gambaran tentang metode ini meminta peneliti di bidang pengabdian kepada masyarakat bukan hanya menyelesaikan masalah personal, melainkan pemecahan masalah kumpulan masyarakat. Berawal dari kegiatan di atas kegiatan PAR dimulai dengan panggilan data secara observasi dan wawan cara masalah yang dominan pada dusun langsat desa semambung khususnya yang nantinya di angkat sebagai masalah utama. Dari hasil observasi dan wawan cara kemudian di lakukan pengolahan data, penetapan masalah yang paling urgen dan mampu di selesaikan oleh TIM PAR di dusun langsat dan langsung di tindak lanjuti dengan melakukan aksi yang relevan dengan permasalahan tersebut bersama masyarakat. Berikut adalah susunan teknik PAR di dusun langsat di desa semambung. Mapping merupakan penggambaran kondisih wilayah secara detail, oleh karena itu untuk menghindari kekeliruan informasi, posisi, dan kondisi penduduk kami mengadakan musyawaroh bersama-sama masyarakat yang bertempat di kediaman bapak Supandi S.Pd selaku kepala dusun langsat desa jatibanteng. Time 
line atau alur sejarah ini di laksanakan untuk mencari informasi tentang sejarah yang peristiwa yang pernah terjadi dalam masyarakat khususnya.

\section{Hasil dan Diskusi}

\section{Persiapan dan Koordinasi}

Program pengabdian kepada masyarakat ini diharapkan berjalan dengan lancar, oleh sebab itu langkah awal yang dilakukan adalah koordinasi internal untuk menyamakan persepsi dan menyusun program yang tepat. Koordinasi antara pihak yang berkepentingan dengan kegiatan ini yakni Tim Pelaksana (dosen) dan Tim Pendamping (mahasiswa), untuk membahas pembagian tanggung jawab setiap anggota pelaksana, penyusunan acara kegiatan dan waktu pelaksanaan. Langkah selanjutnya adalah koordinasi eksternal antara Tim Pelaksana dengan mitra kegiatan, seperti kepala desa Semambung dan tokoh agama. Koordinasi ini membahas tentang gambaran kegiatan, pengaturan kegiatan, pengecekan kesiapan lokasi kegiatan dan calon peserta kegiatan. 


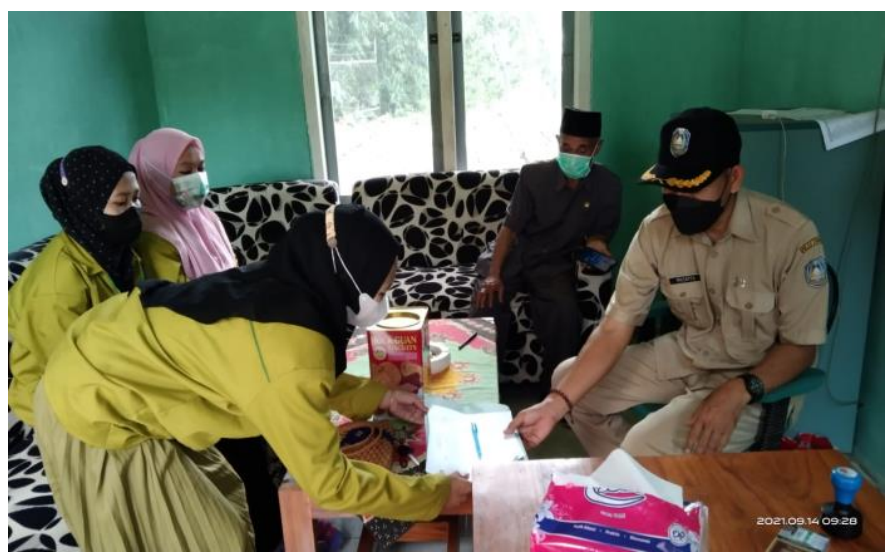

Gambar 1. Koordinasi dengan Kepala dan Perangkat Desa Semambung Matrik Ranking Permasalahan

Setelah mengamati keseluruhan masalah yang ada di dusun langsat, kami menemukan berbagai permasalahan yang menuntut untuk di pecahkan. Namun dari berbagai masalah yang timbul tersebut, tidak mungkin tim dapat menyelesaikan semuanya. Akhirnya, tim beserta masyarakat membuat kesepakatan untuk memfokuskan pada satu masalah yang dirasa mampu untuk di selsaikan secara bersamasama.

Kemudian, kami beserta masyarakat menyusun bagian peringkat (matrik ranking) dari masalah-masalah tersebut, yaitu bagian yang di Vol. 3 No.2, Oktober 2021 Lailatul Hasanah, Dkk| 308 gurnal Pengabdian Masyarakat 
gunakan untuk menganalisis dan membandingkan masalah-masalah yang telah diidentifikasikan dalam bentuk rangking atau skor. Dengan matrik ini dapat di ketahui peringkat masalah yang ada sehingga dapat dipilih mana akar masalah yang di rasa lebih urgen dan mendesak untuk diselesaikan untuk lebih jelasnya matrik rangking dapat di lihat pada lampiran. Selanjutnya tim menindak lanjuti matrik rangking tersebut dengan menganalisanya, mana masalah yang di anggap lebih urgen dan dapat di pecahkan sesuai dengan kemampuan masyarakat dan tim.

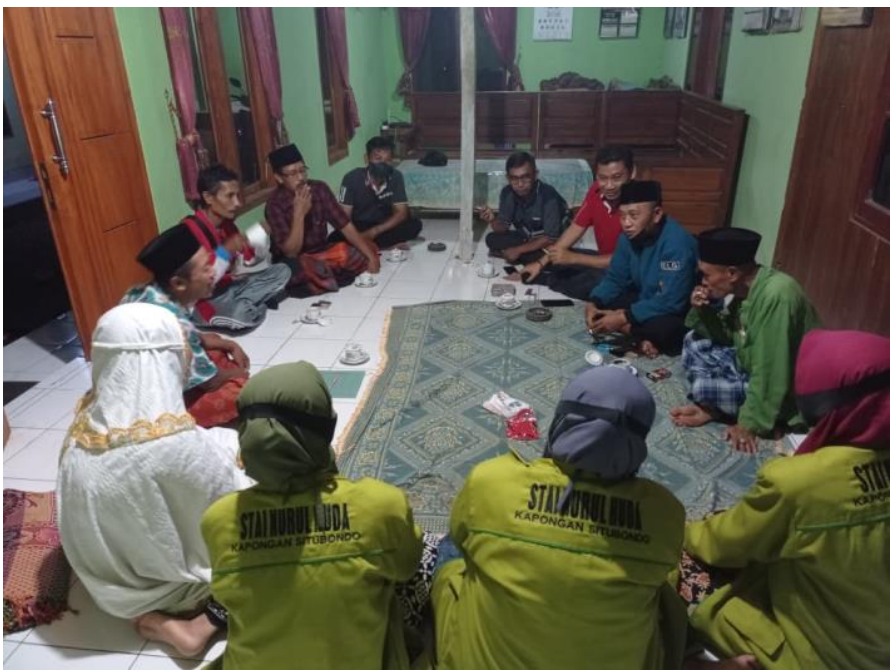

Gambar 2. Tim Berdiskusi dengan Tokoh Masyarakat Terkait Akar Permasalahan di Desa Semambung 


\section{Perencanaan dan Proses Pelaksanaan}

Pada tahap perencanaan dilapangan, dari permasalahnpermasalahan yang di anggap paling relevan dan berpotensi untuk di carikan solusinya bersama masyarakat dan tim, maka disusun sebuah perencanaan lapangan. Adapun topik inti dari perencanaan lapangan tersebut adalah memberikan dampingan tentang memberikan pelatihan tentang Fiqih Wanita yang menghususkan pada Darah Haid Dan Sejenisnya.

Kemudian, Sebelum aksi dilaksanakan, tim meminta persetujuan dengan para tokoh masyarakat dan ibu Muslimat/Fatayat, kapan dan dimna aksi ini dilaksanakn. Akhirnya tim membentuk ke panitiaan dan action di laksanakan bertempat di Madrasah Miftahul Jinan. Kegiatan menarik antusias para peserta ibu muslimat/Fatayat karena setelah diberikan teori langsung peraktek pembuatan di lapangan. 


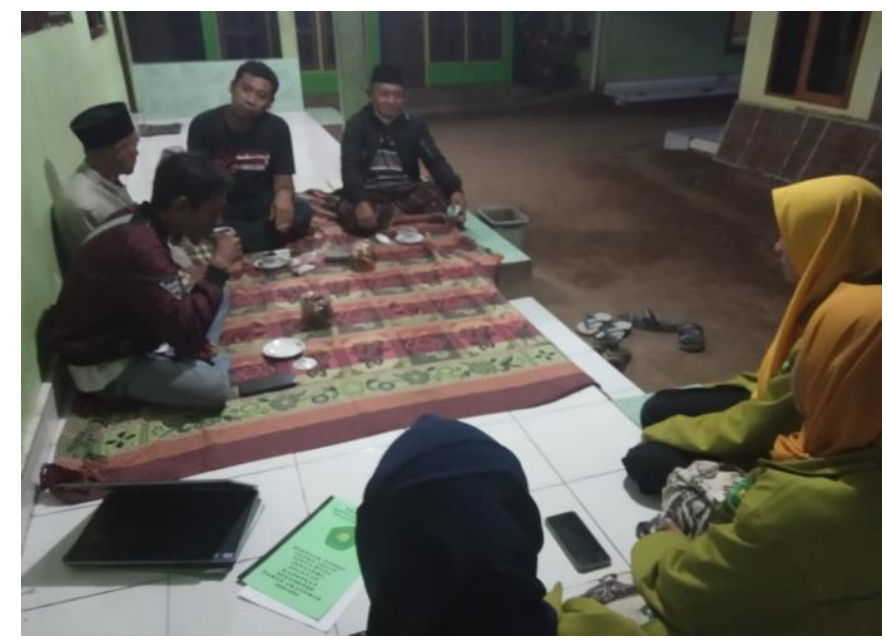

Gambar 3. Meminta Persetujuan Kepada Tokoh Agama dan Masyarakat Tentang Tempat Pelaksanaan

Setelah disetujui, barulah tahap pelaksanaan di adakan di Madrasah Miftahul Jinan dengan diikuti oleh peserta dari tokoh desa, kelompok Ibu Muslimat/fatayat, dan masyarakat. Tim mengundang narasumber yang professional dan menjadikan Ibu Nyai Afifah, S.Pd sebagai pemateri tentang fiqih wanita. Ketika pelaksanaan suasana yang kondusif dan penuh semangat sangat terlihat selama kegiatan langsung. Harapan diadakannya penyuluhan darah Wanita dan sejenisnya dapat

Vol. $3 \mathrm{No.2,}$, Oktober 2021
Lailatul Hasanah, Dkk | 311 gurnal Pengabdian Masyarakat 
membentuk kesadaran masyarakat tentang besarnya dampak negative yang akan di terimah oleh masyarakat apabila tidak memahami darah Wanita dan sejenisnya.
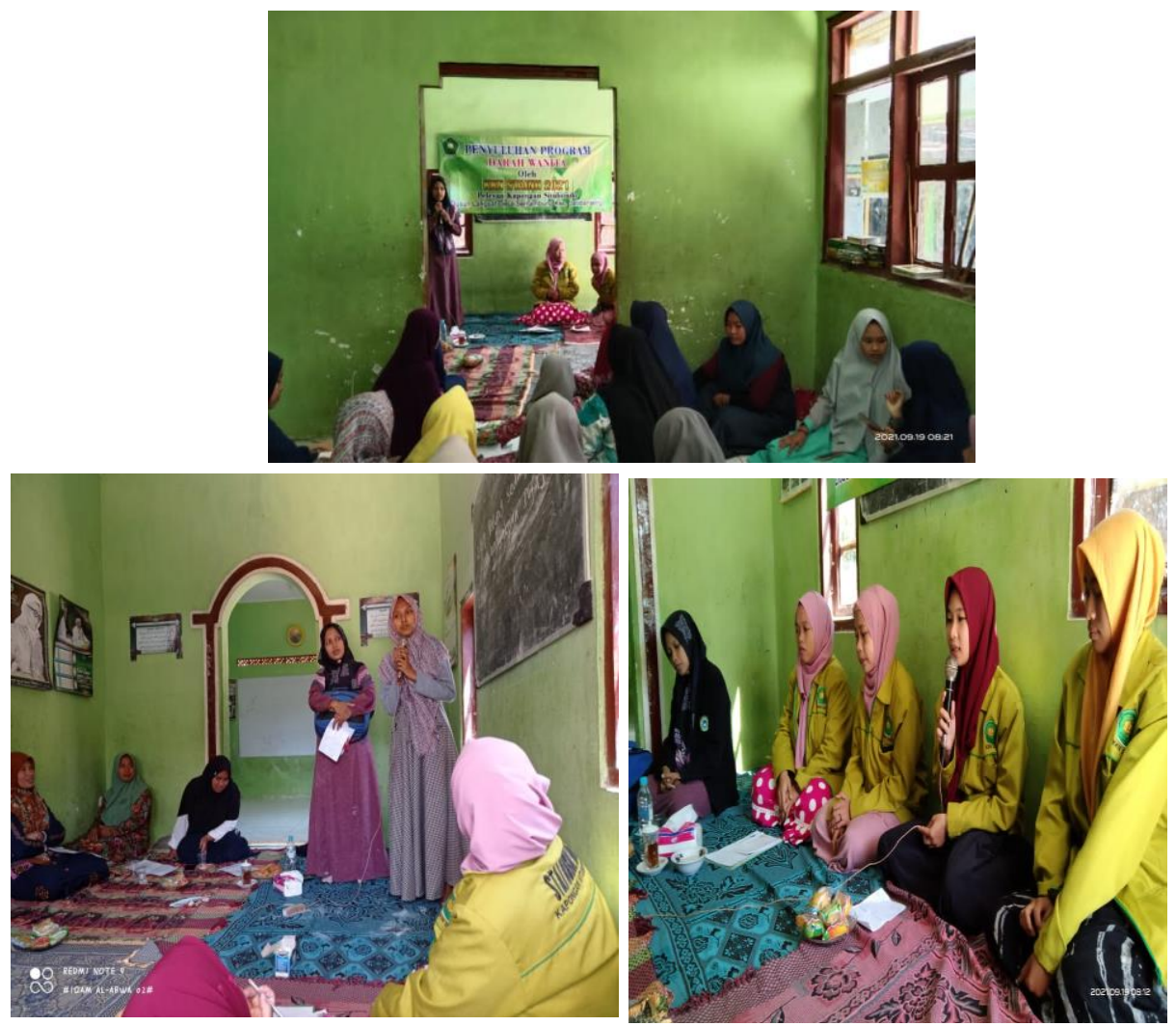

Gambar 4. Proses Pelaksanaan Dampingan Fiqih Wanita di Desa

Semambung

Dari palaksanaan fiqih wanita yang dilakukan oleh Ibu Nyai Vol. 3 No.2, Oktober 2021

Lailatul Hasanah, Dkk| 312 gurnal Pengabdian Masyarakat 
Afifah, S.Pd pada tanggal 13, 20, 27 September yang bertepatan di Madrasah Miftahul Jinan, dan dihadiri oleh beberapa kaum wanita yang bergantian setiap kelompoknya, sehingga masyarakat dapat menumbuhkan kesadaran akan bagaimana konsep dan praktik yang benar tentang sebelum dan sesudah haid terjadi. Ini membuktikan adanya perubahan sosial yang terjadi akibat proses stimulus yang diberikan oleh pemateri kepada audiens ${ }^{1}$. Pengabdian ini sejalan yang pernah dilakukan Fadhli namun berbeda tempat dan tatacara penerapannya ${ }^{2}$.

Dari konsep dan aturan tentang haid itu sendiri secara hukum Islam, menjadikan pedoman yang harus dilakukan dan dilaksanakan oleh kaum wanita seperti contoh kaum wanita di Desa Semambung. Para kaum wanitanya ada yang tidak paham tentang tetap melakukannya puasa ketika haid. Ini menjadikan dua perspektif budaya masyarakat dan hukum Islam. Masyarakat kaum wanita di Desa Semambung memiliki budaya tetap melakukan puasa ketika haid. Padahal secara hukum agama berpuasa ketika hadi tidak

1 Tran and Smith, "The Impact of Employer-Sponsored Educational Assistance Benefits on Community College Student Outcomes."

${ }^{2}$ Fadhli et al., "Peningkatan Pemahaman Haid Melalui Kajian Fiqih Wanita Di Desa Barong Sawahan."

Vol. $3 \mathrm{No.2,}$, oktober 2021 Lailatul Hasanah, Dkk| 313 gurnal Pengabdian Masyarakat 
diperbolehkan ${ }^{3}$.

Terkait haid, proses merupakan siklus yang biasa terjadi dan dialami oleh kaum wanita yang telah matang masa reproduksinya. Bisa dikatakan bahwa wanita yang telah mengalami haid merupakan wanita yang telah dewasa secara seksual, kesuburan, kesehatan tubuh, dan perubahan pertumbuhan tubuh4. Namun realita dilapangan banyak permasalahan terkait haid ini, termasuk berbedanya masa proses haid yang dialami oleh masyarakat khususnya di Desa Semambung. Perbedaan proses hadi ini sudah menjadi permasalahan biasa yang dialami setiap wanita, namun yang menjadi titik tumpu ialah bagaimana setiap kaum wanita memahami aturan dan tatacara ketika memasukinya. Adanya segenap aturan tentang haid (menstruasi) ini menjadikan proses yang sangat berbeda beda, hadi bisa dilihat dari ketentuan warna, waktu dan batasan-batasannya yang begitu rumit, dengan mengingat kondisi siklus perempuan berbeda-beda maka peraturan tersebut dapat dipertanyakan efektivitasnya untuk dijalankan ${ }^{5}$. Selain itu, masyarakat juga memiliki aturan yang tidak

3 Bullah, "Hadis Tentang Perempuan Setengah Akal Dan Agamanya."

${ }^{4}$ Astuti, "Hubungan Indeks Masa Tubuh (Imt) Dengan Dismenorea Pada Remaja."

${ }^{5}$ Murni, "Kesehatan Reproduksi Menurut Al-Quran Surat Al-Baqarah/2 Ayat 222223."

Vol. $3 \mathrm{No.2,}$ Oktober 2021

Lailatul Hasanah, Dkk| 314 qurnal Pengabdian Masyarakat 
tertulis menjadi pedoman dalam kehidupan berbudaya disetiap masung-masing daerah, seperti perempuan yang sedang haid tidak boleh memotong kuku, tidak boleh memotong dan membasahi rambut, tidak dibolehkan memberikan kosmetik maupun aksesoris lainnya pada tubuh wanita. Aturan ini menjadikan pro dan kontra karena aturan tidak tertulis ini tidak terdapat dalam teks-teks agama, baik al- Qur'an maupun hadis. Banyak sekali hadis yang menjelaskan tentang haid, baik interaksi Nabi saw dengan istri-istri beliau yang sedang menstruasi maupun masalah hukum yang berkaitan dengan haid ${ }^{6}$. Seperti juga secara ilmu agama, bahwa wanita yang sedang mengalami haid masih dapat beribdah kepada Allah, SWT dengan beberapa praktiknya antara lain bersedekah, beramal, mengaji, istighfar, dan zikir ${ }^{7}$.

\section{Kesimpulan}

Permasalajan tentang pengaplikasian hukum Islam di masyarakat luas masih banyak yang tidak mengikuti sunnatullah, termasuk di Desa Semambung. Banyak kaum wanita di desa ini yang masih belum mengerti tentang tatacara pelaksanaan sebelum dan sesudah haid, seperti 1) ketika sudah haid masyarakat jarang mengganti pakaiannya;

${ }^{6}$ Dahri, "Reproduksi Perempuan Dalam Perspektif Islam (Tinjauan Terhadap Haid, Nifas, Dan Istihadhah)."

${ }^{7}$ Rahmah, "Wanita Haid Dengan Metode Syarah Perspektif Teologi Islam."

Vol. $3 \mathrm{No.2,}$, oktober 2021

Lailatul Hasanah, Dkk| 315 Zurnal Pengabdian Masyarakat 
2) masih berpuasa ketika masih haid; 3) kurang paham batas waktu tentang haid; 4) cara menghitung haid belum memahami; 5) masyarakat masih belum paham tentang istihadhah. Ini menjadi permasalahan dasar yang harus segera diperbaiki, agar masyarakat tidak terjerumus pada kesalahan yang berlanjut dan melanggar perintah Allah SWT dan Sunnatullah. Berberapa permasalahan ini dicari akar permasalahannya sehingga ditemukanlah tujuan, untuk memahamkan masyarakat Desa Semambung terkait darah haid khusus kaum wanita. Adapun beberapa proses yang telah dilaksan untuk mensukseskan tujuan tersebut. Pertama, pada tahapan pra pelaksanaan yang telah berkoordinasi dengan berbagai pihak pemerintahan dari Kecamatan, Desa, hingga beberapa tokoh agama dan masyarakat. Ini memberikan konsep awal permasalahan yang akan diangkat. Kedua, pada tahap proses perencanaan. Sama halnya pada proses pra perencanaan, namun pada tahap ini lebih menitik beratkan pada akar masalah yang telah ditemukan terkait darah haid khusus kaum wanita. Ketiga, proses pelaksanaan. Pada proses ini laksanakanlah beberapa pemberian materi kepada audiens dan didapatkanlah perubahan sosial masyarakat wanita Desa Semambung, seperti lebih memahami dan memperbaiki proese sebelum dan sesudah haid. Meraka lebih memahami hukum tentang 
haid. Namun kami sangat menyadari bahwa proses yang telah dilakukan tidaklah sempurna, maka butuh beberapa masukan dan refisi kedepan. Juga harapan kedepan, terdapat penelitian yang mengkhususkan pada peran berbagai tokoh dimasyarakat yang mensukseskan beberapa kegiatan kemahasiswaan, karena pada pengabdian ini peran beberapa tokoh sangat berpengaruh sekali dalam mensukseskan program.

\section{Daftar Pustaka}

Astuti, Endah Puji. "Hubungan Indeks Masa Tubuh (Imt) Dengan Dismenorea Pada Remaja." Jurnal Kebidanan 9, no. 02. 2018.

Bullah, Habib. "Hadis Tentang Perempuan Setengah Akal Dan Agamanya." Tahdis: Jurnal Kajian Ilmu Al-Hadis 11, no. 2 (n.d.).

Dahri, Nurdeni. "Reproduksi Perempuan Dalam Perspektif Islam (Tinjauan Terhadap Haid, Nifas, Dan Istihadhah)." Marwah: Jurnal Perempuan, Agama Dan Jender 11, no. 2. 2012.

Fadhli, Khotim, Azizah Azhari, Muhamad Hamim Thohari, and Kholis Firmasyah. "Peningkatan Pemahaman Haid Melalui Kajian Fiqih Wanita Di Desa Barong Sawahan." Jumat Keagamaan: Jurnal Pengabdian Masyarakat 2, no. 2. 2021.

Murni, Dewi. "Kesehatan Reproduksi Menurut Al-Quran Surat AlBaqarah/2 Ayat 222-223." Jurnal Ulunnuha 8, no. 2. 2019.

Rahmah, Siti. "Wanita Haid Dengan Metode Syarah Perspektif Teologi Islam." Jurnal Penelitian Ilmu Ushuluddin 1, no. 2. 2021.

Tran, Henry, and Douglas Smith. "The Impact of Employer-Sponsored Educational Assistance Benefits on Community College Student Outcomes." Journal of Student Financial Aid 47, no. 2. 2017.

Vol. $3 \mathrm{No.2,}$, oktober 2021

Lailatul Hasanah, Dkk| 317 Zurnal Pengabdian Masyarakat 


\section{JURNAL}

\section{As-Sidanah}

\section{Vol. 03 No. 2, Desember 2021}

